\title{
A Review: Antioxidant Activities of Sembung Leaves (Blumea Balsamifera (L.) DC)
}

Septi Dwi Putri ${ }^{1}$, Rusdi ${ }^{1}$ and Ridho Asra* ${ }^{1}$

${ }^{1}$ School of Pharmaceutical Science (STIFARM) Padang, Indonesia

Article History

Received:30.08.2020

Accepted: 11.09 .2020

Published: 30.09 .2020

Journal homepage:

https://www.easpublisher.com/easipp

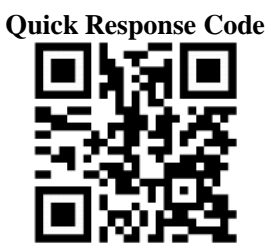

Abstract: Sembung (Blumea balsamifera (L.) DC) is a drug that is widely used for treatment in various countries such as Indonesia, China, the Philippines and other countries. In Indonesia it has various other names, in West Sumatra it is called Capo leaf and sembung. In China it is better known as ainiaxing. Sembung is used as an ancient medical medicine. It has many uses, namely for antioxidants, for wound healing, antibacterial, anti-malarial, as well as xanthine oxidase inhibitors. Antioxidants are inhibitors in the oxidation process so that they can protect cells from the dangers of free radical.

Keywords: Blumea balsamifera (L.) DC, sembung, phytochemicals, antioxidants

Copyright (9) 2020 The Author(s): This is an open-access article distributed under the terms of the Creative Commons Attribution 4.0 International License (CC BY-NC 4.0) which permits unrestricted use, distribution, and reproduction in any medium for non-commercial use provided the original author and source are credited.

\section{INTRODUCTION}

The leaves of sembung, with the scientific name of Blumea balsamifera (Sudirga, S. K. 2012) from the Asteraceae family, are also an ancient medical herb (Hong, L. et al., 2015). Based on research tests, sembung leaves contain chemical compounds such as essential oils, tannins, limonene, resin and camphor (Sudirga, S. K. 2012), alkaloids, flavonoids, and steroids (Jumariswan., Sari, I. et al., 2017). The results of phytochemical research from the sembung plant showe that it contained four classes of flavonoids such as flavonols, flavones, flavanones, and dihydroflavonols and their derivatives (Nessa, F. et al., 2010).

Sembung leaves have been widely used in various Southeast Asian countries such as Malaysia, Thailand, Vietnam, the Philippines, China. In China, this sembung leaf plant is used for the treatment of eczema, dermatitis, beriberi, lumbago, menorrhagia, rheumatism, skin damage and insecticides (Hong, L. et al., 2015; \& Chen, M. et al., 2010), healing wounds on the skin (Shedoeva, A. et al., 2019), abdominal pain, fractures and childbirth (Sudirga, S. K. 2012). Sembung is a traditional medicine that is used for treatment and has been used for generations by parents, friends and neighbors. People often use sembung as a treatment for headaches, colds, fever, diabetes, flatulence, and it is often used by women who are having menstruation to be used as a pain reliever due to menstruation (Firmansyah, N. 2017).

Previous research results showed that sembung leaf extract has antifungal (Jumariswan., Sari, I. et al., 2017), anti-diarrhea (Larasati, E.K. et al., 2015), antihypertensive (Afrianti, R. et al., 2020), antidiabetic, antioxidant (Roy, K. et al., 2013), antibacterial (Binh, H.T. et al., 2020), and antimicrobial (Sakee, U. et al., 2011) activities. In addition, the leaves of sembung can have an antagonistic effect. For example green tea is usually safe but in tablet or capsule form it can cause liver injury, especially in predisposing conditions, such as fever (Saleh, I. et al., 2013). The identification results of the phytochemical content of sembung leaves show more than 100 chemicals such as essential oils, flavonoids, alcohols, dihydroflavones, sterols, organic acids, monoterpenes, sesquiterpenes, triterpenes. Most of the existing studies have investigated flavonoids and essential oils which have both in vivo and in vitro bioactivity effects (Pang, Y. et al., 2014). 


\section{The picture of sembung as shown below:}

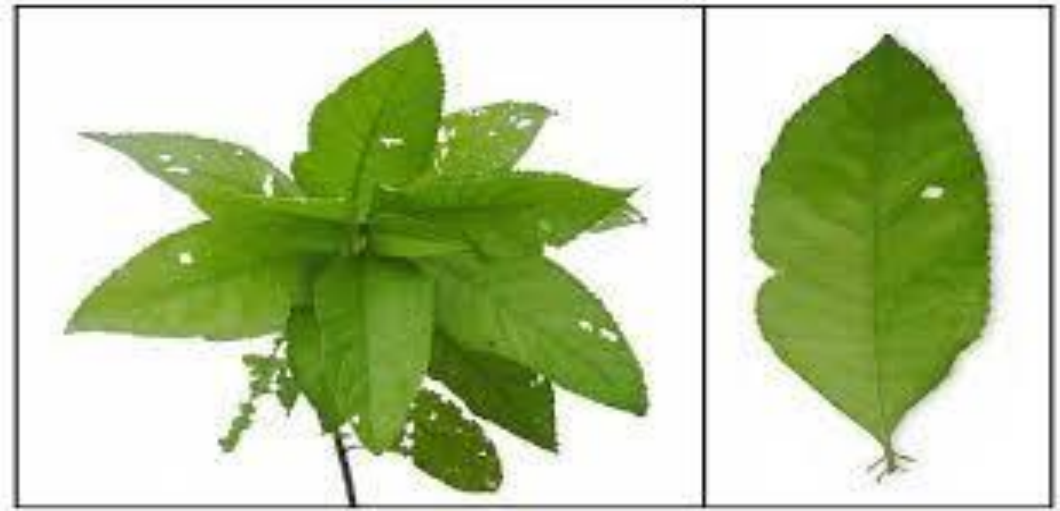

Picture1. Leaf of sembung (Blumea balsamifera (L.) DC) (Pooja, P. et al., 2019)

Taxonomy (https://en.m.wikipedia.org)

$\begin{array}{lc}\text { Division } & : \text { Tracheophyta } \\ \text { Upper Division } & : \text { Spermatophytina } \\ \text { Clade } & \text { : Angiosperms } \\ \text { Clade } & \text { : Mesangiosperms } \\ \text { Clade } & : \text { Eudicots } \\ \text { Clade } & : \text { Core eudicots } \\ \text { Clade } & : \text { Asterids } \\ \text { Clade } & : \text { Campanulids } \\ \text { Order } & : \text { Asterles } \\ \text { Family } & : \text { Asteraceae } \\ \text { Genus } & : \text { Blumea } \\ \text { Species } & : \text { Blumea balsamifera. (L.) DC }\end{array}$

\section{Data Collection}

Data collection in this review article was carried out by collecting journals, articles and some other sources from the internet that were taken from the previous 10 years (2010-2020). The journals used in making this review article were from international and national journals. In the search to make this review article, some keywords were used, namely, Blumea balsamifera (L.) DC, sembung, phytochemistry, and pharmacology. Then in the search for references used in journal searches, it was done by using the web such as Google Scholar, Researchgate, ScienceDirect, NCBI, Pubmed and trusted journals. Then on journal downloading, some journals could be downloaded directly and some were downloaded using the DOI website.

\section{DISCUSSION}

\section{Antioxidant Activity}

Antioxidant is an inhibitor in the oxidation process so that it can protect cells from the dangers of free radical (Maslahat, M. et al., 2013). Antioxidants consist of two types, namely natural antioxidants and synthetic antioxidants. Natural antioxidants are antioxidants that can be obtained from vegetables, fruits and spices. Synthetic antioxidants such as butyl hydroxy toluene (BHT), but the disadvantage of using synthetic antioxidants is that if it is used excessively it can cause liver damage (Kumar, P. S. et al., 2018). These antioxidants function to prevent oxidation damage to the skin so that premature aging can be resolved (Masaki, H. 2010). The method of analyzing antioxidant activity can be divided into 3 , including the antioxidant activity test using the DPPH, FRAP, and FIC methods. The three methods have been carried out on ascorbic acid, gallic acid, and quercetin. It can be compared to the antioxidant activity test with DPPH found to be the most effective and efficient, while the FIC (Ferrous Ion Chelating) method is the least effective and efficient because of its very low sensitivity and its chelating power is less than $20 \%$. The three test methods have very high correlation $(\mathrm{R}>0.98)$, especially between FRAP and DPPH (Maesaroh, K. et al., 2018). 
Table 1. $\mathrm{IC}_{50}$ values obtained in several different extraction methods for sembung leaves (Blumea balsamifera (L.) DC).

\begin{tabular}{|c|c|c|c|}
\hline Blumea balsamifera (L.) DC & Extraction method & IC value $_{50}$ & Reference \\
\hline Essential oil & Steam distillation & $0.6342 \mathrm{~mL} / \mathrm{mL}$ & (Jiang, Z.L. et al., 2014) \\
\hline Water extract & Steeping & $155.65 \mathrm{~mL} / \mathrm{L}$ & (Maslahat, M. et al., 2013) \\
\hline Water extract & Godongan & $293.80 \mathrm{~mL} / \mathrm{L}$ & (Maslahat, M. et al., 2013) \\
\hline Loloh sembung (sembung herbal drink) & Stew & $99.0 \%$ & (Kusumawati, I.G.A.W. et al., 2016) \\
\hline Ethanol extract & Macerated & $0.021 \mathrm{mg} / \mathrm{mL}$ & (Thach, B. Đ. et al., 2017) \\
\hline Ethyl acetate extract (shoots) & Macerated & $37.09 \mathrm{mg} / \mathrm{L}$ & (Mantra, I.B.K. et al., 2019) \\
\hline Ethyl acetate extract (easy leaves) & Macerated & $71.50 \mathrm{mg} / \mathrm{L}$ & (Mantra, I.B.K. et al., 2019) \\
\hline Ethyl acetate extract (old leaves) & Macerated & $50.14 \mathrm{mg} / \mathrm{L}$ & (Mantra, I.B.K. et al., 2019) \\
\hline
\end{tabular}

The process of obtaining essential oils which will be tested for their antioxidant activity is by using steam distillation using artificial antioxidant agents such as trolox. The IC50 value obtained is essential oil, the IC value is ${ }_{50}=0.6342 \mu \mathrm{L} / \mathrm{mL}$, while the antioxidant agent (comparison) such as trolok has an IC value of ${ }_{50}=$ $0.1873 \mu \mathrm{g} / \mathrm{mL}$. In a study on the antioxidant activity of essential oils from sembung (Blumea balsamifera (L.) DC), it was shown that the $\mathrm{IC}_{50}$ value of essential oils for DPPH free radicals is $0.6342 \mathrm{~mL} / \mathrm{mL}$, which indicates that the essential oil in sembung has high antioxidant activity (Jiang, Z.L. et al., 2014). Good antioxidant activity is also obtained from the essential oil extracted using the hydrodistillation-solvent extraction (HDSE) simultaneous distillation and extraction (SDE) solvent (Wang, Y.H., \& Yu, X.Y. 2018).

Extraction with steeping and boiling is an extraction that can be called as heat extraction because the process of taking the active substance in it uses heat energy. Based on research on the antioxidant activity of the water simplicia extract of sembung leaf, there are two ways to obtain the water extract by steeping and teasing. It was stated that the IC50 values of both of them were still weak and very weak (Maslahat, M. et al., 2013). The ability to ward off free radicals was higher in loloh sembung (sembung herbal drink) by boiling it as shown in the research of the loloh sembung formulation which can produce the highest ability to ward off free radicals at a concentration of $7 \%$ (7 grams of sembung dried powder in $100 \mathrm{~mL}$ of water) which is boiled for 7 minutes has the ability to ward off DPPH free radicals up to its highest of $99.0 \%$ (Kusumawati, I.G.A.W. et al., 2016). Loloh sembung is often used by Balinese people as traditional drink for treatment, as well as green coconut water by Balinese people is often used as a loloh solvent, thus in this study green coconut water solvent was used but the results of antioxidant activity that were obtained from boiled and brewed sembung leaf extract did not have a significant difference (Lusiana, S. et al., 2018).

The aim of this study was to evaluate the antioxidant activity of sembung leaves by macerating ethanol solvent using DPPH to determine the IC50 value, and using ascorbic acid as a comparison and the
IC50 value obtained for the ethanol extract was $=0.021$ $\mathrm{mg} / \mathrm{ml}$, while the ascorbic acid was $=0.021 \mathrm{mg} / \mathrm{ml}$. $0.029 \mathrm{mg} / \mathrm{ml}$. Thus, the antioxidant activity of the ethanol extract was stronger than that of ascorbic acid. Therefore, the ethanol extract of sembung leaves shows that it can be used as an easily accessible source of antioxidants (Thach, B. Đ. et al., 2017). This study aimed to determine the antioxidant activity of 3 types of solvents (water, ethanol, and ethyl acetate) and 3 different types of leaf parts (shoots, young leaves, and old leaves). In this study, the ethyl acetate extract of the leaves of sembung, the shoots, had a low IC50 value which indicated that the antioxidant activity was stronger than the young leaves and old leaves with water and ethanol as solvent used. This was supported by the highest levels of flavonoids ethyl acetate and free radical capacity levels in the shoots of sembung (Mantra, I.B.K. et al., 2019). Huliselan et al., (2015) in a research on the antioxidant activity of the extract ethanol, ethyl acetate and n-hexane of the sesewanua leaves (ClerodendronsquamatumVahl.) stated that the ethyl acetate extract of sesewanua leaves have the highest antioxidant activity with IC50 value of 13.084 ppm. Ethyl acetate extract had a high effect on effectiveness as an antioxidant against DPPH radical (1,1 diphenyl-2-picrylhydrazil). Three types of solvents were used in the extraction process based on different levels of polarity, namely n-hexane, ethyl acetate, and ethanol (non-polar, semi-polar, polar). These differences can affect the results of the content of bioactive compounds, so that the effectiveness of antioxidants from ethyl acetate extract in neutralizing free radicals is thought to be related to the semi-polar nature of ethyl acetate so that many bioactive components are dissolved in it (Huliselan, Y.M. et al., 2015).

\section{Toxicity}

Eriadi et al., (2019) reported that two-way ANOVA statistical calculations on testing 3 different dosage variations on the SGPT value with a value of $p$ $=0.770(\mathrm{P}>0.05)$, meaning that there was no significant effect of dose variations on SGPT activity in male white mice. Then it can be seen from the length of time given to the SGPT significance value of $0.707(\mathrm{P}>$ $0.05)$, meaning that there is no significant effect of the length of time of administration on SGPT activity in 
male white mice. It can be concluded that statistically administration of sembung leaf extract (Blumea balsamifera (L.) DC) in a subacute way did not have a significant toxic effect on liver function (Eriadi, A. et al., 2019).

\section{Wound healing}

This research was conducted clinically to determine the function of sembung leaf oil that was stated to improve wounds healing in mice by promoting angiogenesis, perfusion, collagen deposition, formation of tissue organized granulation, reepithelization, and wound closure (Pang, Y. et al., 2014).

\section{Antibacterial}

Activity test of the ethanol extract of sembung leaves against acne-causing bacteria Propionibacterium acnes was carried out in vitro. The leaves of sembung were extracted with ethanol as a solvent, and then the agar diffusion method was carried out with concentrations of $5 \%, 10 \%, 15 \%, 20 \%, 25 \%, 50 \%$ and $75 \%$ levels. This proves that the ethanol extract of sembung (Blumea balsamifera L) has anti-acne activity against Propionibacterium acnes with the largest concentration of $75 \%$ with an inhibitory diameter of $2.26 \mathrm{~cm}$. The Minimum Inhibitory Concentration (MIC) value for Propionibacterium acnes at a concentration of $5 \%$ was with an inhibitory diameter of $0.93 \mathrm{~cm}$ (Thamrin, A.A. et al., 2016).

Research conducted by previous researchers reported that the loloh of sembung which was carried out by boiling and brewing using leaves that were derived from dried and non-dried sembung showed that it did not provide inhibition against Escherichia coli and Staphyrilococcus aureus bacteria (Kusumawati, I.G.A.W., \& Yogeswara, I.B.A. 2016). Therefore it is very necessary in determining what solvent to use.

The cell wall of $\mathrm{S}$. aureus (Gram positive bacteria) has a cell wall structure with many layers of peptidoglycan and relatively few lipids, while E. coli (Gram negative bacteria) has a more complex structure, where there is an outer membrane that protects the peptidoglycan, namely phospholipids (inner layer) and lipopolysaccharide (outer layer), so that the test extract is difficult to penetrate and interfere with the integrity of the bacterial cell wall (Sartinah, A. et al., 2010; \& Gilbert, A., et al., 2016). Sakee et al., (2011) reported that the leaf extract of sembung using dichloromethane was unable to inhibit S. aureus bacteria. Meanwhile, sembung leaf extract using hexane solvent can inhibit S. aureus bacteria (Sakee, U. et al., 2011).

\section{Antimalarial}

This research was conducted with the aim of obtaining information from an area about plant species that have the potential for anti-malarial activity, one of which is in the Indonesian Kupang region. Plant contains flavonoids, terpenes, lactones, cineol, borneol, camper, tannins, limonene, palmitin acid, miristin, alcohol, seskuiterpen, dimethyl ether kloroasetofenon, pyrocatechin, glycosides and saponins. Ethyl acetate fraction contains polyphenols, tannins, flavonoids, and monoterpene, sesquiterpene, and quinone compounds. The results of characterization using UV spectrophotometry and infrared spectrophotometry for the active fraction of ethyl acetate identified lactone sesquiterpene compounds (blumealactone) which have anti-plasmodium activity at a dose of $118 \mathrm{mg} / \mathrm{kg} \mathrm{BW}$ with inhibition percentage $17.53 \%$ (Ihwan., \& Koda, S.H.A. 2017). Indonesian people, such as those in the Sei Kepayang area, North Sumatra, use sembung stew as an antimalarial drug (Abdillah, S. et al., 2014). Abdillah et al., also reported that the methanol extract of sembung leaves was effective in killing the Plasmodium falciparum strain 3D7 parasite which causes malaria which is sensitive to the antimalarial drug chloroquine. Further in vivo testing of mice infected with the P. falciparum parasite NK 65 strain gave positive results of sembung leaf extract as an antimalarial drug (Abdillah, S. et al., 2015).

\section{Inhibitor of Xanthine Oxidase}

Leaf extract of sembung has activity as an inhibitor of xanthine oxidase activity, as well as a drug to reduce uric acid levels (Le Nguyen Tu Linh, B. D. et al., 2017). The inhibition of xanthine oxidase activity is due to the presence of polyphenol compounds found in plants such as flavonoids (Spanou, C. et al., 2012). It has been found that the methanol extract of sembung has a higher xanthine oxidase inhibition value compared to the chloroform extract and pet-ether extract. Likewise with its IC50 value, the methanol extract of the leaves of sembung was higher than the chloroform extract and pet-ether extract (Nessa, F. et al., 2010).

\section{Types of Extraction of Sembung leave}

Extraction can be done in cold and hot mechanism. Cold method that can be used, one of them, is maceration (stirring); and hot methods that can be used are reflux, socletation, infusion.

\section{Extraction Using the Maceration Method (Cold Method)}

The maceration process by immersing is carried out several times at room temperature. The advantage of this method is that it is easy and does not need heating so that natural materials are less likely to be damaged. The selection of solvents based on their solubility and polarity facilitates the separation of natural substances in the sample. If the polarity of the solvent used is different, the extraction results obtained will also be different. The long operation of the maceration method and the stationary state during maceration allows many compounds to be extracted (Setyati, W.A. et al., 2017). Extraction is carried out 3 times by replacing the saturated solvent with the new solvent so that if the first stage the extraction results are not sufficient, then the second and third stages can be 
carried out until the desired extraction results are obtained.

\section{Extraction with the Socletation Method (Hot Method)}

Extraction using the socletation method is principally a heating process that can increase the ability to extract compounds that are insoluble at room temperature, so that the compound withdrawal activity is maximized. The weighed simplicia is wrapped in filter paper, then tied with threads at the two ends of the filter paper, next, enter the solvent determined by the researcher with the specified amount into the so-called flask, the solvent is also put into the shock tube to soak the sample. Perform soxhletation until the color changes to a clear color. Then evaporation should be done with a rotary evaporator so as to get a thick extract (Sa'adah, H. et al., 2017).

\section{Extraction Using the Reflux Method (Hot Way)}

Extraction using the reflux method, in principle, is the extraction process by heating using a solvent so that it will evaporate at high temperature, then it will be cooled with a condenser so that a condensation process occurs on the condenser and then it will fall back into the reaction container so that the solvent will remain during the reaction. Then, the solution was filtered with gauze, then the filtrate obtained would be evaporated with a rotary evaporator and then it should be oven-dried for several days with a predetermined temperature of about $50^{\circ} \mathrm{C}$ (Susanty., \& Bachmid, F. 2016).

Extraction can be done cold and hot. Extraction carried out in cold is usually like maceration, which means extraction by soaking fresh or dry plants using various solvents. The content of antioxidants is an ingredient that is not heat resistant, so if an extraction method such as reflux (heat) is used, it is thought that it will cause a low value of antioxidant activity and can interfere with the antioxidant activity contained in the simplicia to be tested (Sie, JO 2013).

\section{Phytochemicals}

It was reported that $70 \%$ ethanol extract in sembung contains flavonoids, steroids, tannins, quinones, and saponins (Septiana, E. et al., 2017). The difference in the chemical compound content of sembung leaves achieved by different researchers is due to differences in the method of extraction, type of solvent, as well as because of differences in the comparators used (Sopianti, D.S. et al., 2019). The essential oil composition of sembung leaves is 1-Octen3-ol; linalool; chrysanthenone; 3,3-Dimethyl-6methylene-cyclohexene; Campora; l-Borneol; 2,2,8Trimethyltricyclo [6.2.2.01,6] dodec-5-ene; Thujopsene- (12); (+) - a-longipine; Eugenol; Dehydroaromadendrene; Thujopsene-13; Dichloroacetic acid, 2- (1-adamantyl) ethyl ester; 2,3,4,5-Tetramethyltricyclo [3.2.1.12,7] oct-3-ene;
Dimethoxydurene; $\beta$-Cadinene; $\alpha$-Caryophyllene; (+) Aromadendrene; 4-Methoxy-3-tert-butylphenol; [(1S, 2S, 4R) -1,3,3-Trimethyl-norbornan-2-yl] acetate; $\delta$ Cadinene; (-) - Globulol; Elemol; ( \pm ) - trans-Nerolidol; Caryophyllene oxide; Guaiol; 1- (1-Oxobutyl) -1,2dihydropyridine; Ledol; $\gamma$-Maaliene; $\alpha$-Cuparenol; gEudesmol; Alloaromadendrene oxide- (1); $\beta$-Eudesmol; Selina-6-en-4-ol; Xanthoxylin; 3-Ethyl-3-hydroxyandrostan-17-one; Tetradecanal; (-) - Spathulenol; 1 (+) - Ascorbic acid 2,6-dehexadecanoate; 1,7,7Trimethylbicyclo [2.2.1] heptan-2-yl-3methylenecyclopentane-carboxylate; Phytol; Linoleic acid; Tetrahydrofuran-2-carboxylic acid, (9-oxo-9Hfluorene-2-yl) amide; Cyclopropanecarboxylic acid, 1methyl-, 2,6-bis (1,1-dimethyl-ethyl) -4-methylphenyl ester (Yuan, Y. et al., 2016).

\section{Conclutions}

The leaves of sembung (Blumea balsamifera (L.) DC) contain chemical compounds such as flavonoids, steroids, tannins, quinones, and saponins, essential oils. The antioxidant activity between leaves of stew, steeped sembung, and also those that are using ethanol, methanol, and ethyl acetate solvents indicates that ethyl acetate has a higher antioxidant activity. Apart from antioxidant activity, sembung is also used for wound healing, antibacterial activity, anti-malarial activity, and as xanthine oxidase inhibitor. Extraction methods that have been used in research on sembung are maceration and steam distillation; some other usages also exist such as making sembung as traditional herbs by steeping and stewing, or also often called as godongan.

\section{REFERENCES}

1. Sudirga, S. K. (2012). Utilization of Plants as Traditional Medicine in Trunyan Village, Kintamani District, Bangli Regency. E J. Bumi Lestari. 4 (2), 7-18.

2. Hong, L., Guo, Z., Huang, K., Wei, S., Liu, B., Meng, S., \& Long, C. (2015). Ethnobotanical study on medicinal plants used by Maonan people in China. Journal of Ethnobiology and Ethnomedicine. 11 (32), 2-34.

3. Jumariswan., Sari, I., Nursanty, R., \& Suwarno. (2017). Antifungal Test of Sembung Leaf Ethyl Acetate Extract (Blumea balsamifera (L.) DC) Against Fluconazole Resistant Candida Albicans Fungal Growth. Biotic National Seminar. 4 (1), 392-396.

4. Nessa, F., Ismail, Z., \& Mohamed, N. (2010). Xanthine oxidase inhibitory activities of extracts and flavonoids of the leaves of Blumea balsamifera. Pharmaceutical Biology. 48 (12), 1405-1412.

5. Chen, M., Qin, J. J., Fu, J. J., Hu, X. J., Liu, X. H., Zhang, W. D., \& Jin, H. Z. (2010). Blumeaenes A$\mathrm{J}$, sesquiterpenoid esters from Blumea balsamifera 
with NO inhibitory activity. Planta Medica, 76(09), 897-902.

6. Shedoeva, A., Leavesley, D., Upton, Z., and Fan, C. (2019) Wound Healing and the Use of Medicinal Plants, " Evidence-Based Complement. Altern. Med; Figure 1, 1-30. doi: 10.1155 / 2019/2684108.

7. Firmansyah, N. (2017). Utilization of Sembung leaves (Blumea balsamifera) as Traditional Medicine in Javanese Village, Kejuruan Muda District, Aceh Tamiang District, 2015. National Biotic Seminar. 4 (2), 8-13.

8. Larasati, E.K., Ahmad, I., \& Ibrahim, A. (2015). Antidiarrheal Effects of Sembung Leaf Extract (Blumea Balsamifera L.) Against White Mice. Journal of Science and Health. 1 (2), 56-60. doi: 10.25026 / jsk.v1i2.17.

9. Afrianti, R., Novelni, R., \& Yulinda, I. (2020). Effect of Giving Ethanol Extract of Sembung Leaves (Blumea balsamifera (L.) DC) as Antihypertensive Against Male White Rats. Journal of the Prayoga Pharmacy Academy. 1 (1), 13-18.

10. Roy, K., Saha, S., Biswas, S., Ahmed, W., \& Mariappan, G. (2013). In vivo assessment of antidiabetic and antioxidant activities of Blumea balsamifera in streptozotocin-diabetic rats. Research Journal of Medicinal Plant. 7 (1), 48-57. doi: 10.3923 / rjmp.2013.48.57.

11. Binh, H.T., Tri, N.M., Quan, N.H., \& Ngoc, N.V. (2020). Antibacterial Activities and Chemical Composition Of Essential Oil Of Blumea balsamifera (L.) DC., Distributed In Lamdong Province, Vietnam. Dalat University Journal Of Science. 10 (2), 3-13.

12. Sakee, U., Maneerat, S., Tim Cushnie, TP, \& Deeknamkul, W. (2011). Antimicrobial activity of Blumea balsamifera (Lin.) DC. extracts and essential oils. Natural Product Research. 25 (19), 1849-1856. doi: 10.1080 / 14786419.2010.485573.

13. Saleh, I., Ali, Z., Abe, N., Wilson, F., Hamada, F., Abd-Ellah, M., Walker, L., Khan, I., \& Ashfaq, M. (2013). Effect of green tea and its polyphenols on mouse liver. Phytoterapia. 90, 151-159.

14. Pang, Y., Wang, D., Fan, Z., Chen, X., Yu, F., Hu, X., Wang, K., \& Yuan, L. (2014). Blumea balsamifera- A phytochemical and pharmacological review. Molecules. 19 (7), 94539477. doi: 10.3390 / molecules19079453.

15. Pooja, P., Pinesh, p., Gajera, V., Lambole, V., \& Shah, D.P. (2019). Pharmacological Activities of Blumea Balsamifera L.Dc: an Overview. An International Journal of Pharmaceutical Sciences. $10(1), 44-56$.

16. https://en.m.wikipedia.org/wiki/Blumea_balsamifer $\underline{\mathrm{a}}$

17. Maslahat, M., Nurilmala, F., \& Harpeni, L. (2013). Antioxidant Activity of Sembung Leaf Simplisia Water Extract (Blumea balsamifera). Natural Sciences, University of Nusa Bangsa. 3 (2), 129136.
18. Kumar, P. S., Sucheta, S., Deepa, V. S., Selvamani, P., \& Latha, S. (2008). Antioxidant activity in some selected Indian medicinal plants. African Journal of Biotechnology, 7(12),1826-1828.

19. Masaki, H. (2010). Role of antioxidants in the skin: Anti-aging effects. Journal of Dermatological Science. 58 (2), 85-90. doi: 10.1016 / j.jdermsci.2010.03.003.

20. Maesaroh, K., Kurnia, D., \& Anshori, JA (2018). Comparison of DPPH, FRAP and FIC Antioxidant Activity Test Methods Against Ascorbic Acid, Gallic Acid and Quercetin. Chimica et Natura Acta. $6(2), 93-100$.

21. Jiang, Z.L., Zhou, Y., Ge, W.C., \& Yuan, K. (2014). Phytochemical compositions of volatile oil from Blumea balsamifera and their biological activities. Pharmacognosy Magazine. 10 (39), 346352. doi: 10.4103 / 0973-1296.137377.

22. Wang, Y.H., \& Yu, X.Y. (2018). Biological Activities and Chemical Compositions of Volatile Oil and Essential Oil from the Leaves of Blumea balsamifera. TEOP. 21 (6) 2018, 1511 - 1531.

23. Kusumawati, I.G.A.W., Darmawijaya, I.P., Yogeswara, I.B.A, Santoso, U., \& Marsono, Y. (2016). Formulation and Ability to Counteract Free Radicals from Loloh Sembung (Blumea balsamifera). 1-12.

24. Lusiana, S., Kusumawati, I.G.W.A., Putra, A.M.W.A., \& Yogeswara, I.B.A. (2018). Identification of Asama $\gamma$-Aminobutyrate (GABA) Content and Antioxidant Activity of Sembung (Blumea balsamifera (L.) DC) Extracted Green Coconut Water (Cocos nucifera 1) as an AntiHypertensive Functional Drink. National Seminar. 167-174.

25. Thach, B. Đ., Dao, V. Q., Giang, T. T. L., Cang, D. T., Linh, L. N. T., Ben, T. T., ... \& Suong, N. K. (2017). Antioxidant and antityrosinase activities of flavonoid from Blumea balsamifera (L.) DC. leaves extract. European Journal of Research in Medical Sciences Vol, 5(1).

26. Mantra, I.B.K., Putra, I.N.K., \& Wrasiati, L.P. (2019). Characterization of Bioactive Compounds of Sembung Leaf Extract (Blumea balsamifera (L.) DC) from several types of solvents. Scientific Journal of Food Technology. 6 (1), 54-65.

27. Huliselan, Y.M., Runtuwene, M.R.J., \& Wewekang, D.S. (2015). Antioxidant Activity of Ethanol, Ethyl acetate, and n-Hexane Extracts from Sesewanua Leaves (Clerodendron squamatum Vahl.). Pharmacon. 4 (3), 155-163.

28. Eriadi, A., Ifora., \& Alfiah, S. (2019). Sub-Acute Toxicity Test of Ethanol Extract of Sembung Leaves (Blumea balsamifera L. DC) on Liver and Kidney Function in Male White Mice. Higea Journal of Pharmacy. 11 (1), 23-31.

29. Pang, Y., Wang, D., Hu, X., Wang, H., Fu, W., Fan, Z., Chen, X., Yu, F. (2014). Effect of volatile oil from Blumea Balsamifera (L.) DC. leaves on 
wound healing in mice. Journal of Traditional Chinise Medicine. 34 (6), 716-724.

30. Thamrin, A.A., Yuniarni, U., \& Hazar, S. (2016). Antibacterial Activity Test of Ethanol Extract of Sembung Leaves (Blumea Balsamifera L) Against Acne-causing Bacteria Propionibacterium acnes. Pharmacy Proceedings. 2, 39-44.

31. Kusumawati, I.G.A.W., \& Yogeswara, I.B.A. (2016). Antioxidant And Antibacterial Capacity Of Loloh Sembung (Blumea balsamifera) Based On Extraction Method. Traditional Medicine Magazine. 21 (3), 143-148.

32. Sartinah, A., Astuti, P., \& Wahyuono, S. (2010). Isolation and Identification of Antibacterial Compounds from Chinese Petai Leaves (Leucaena leucocephala (Lam.) De Wit.). Traditional Medicine Magazine. 15 (3), 22-28.

33. Gilbert, A., Herve, TT, William, YN, Leonard, SF, Jules-Roger, K., \& Albert, K. (2016). Antidiarrhoeal and antibacterial activity of aqueous and methanolic leaves extracts of Dissotis thollonii Cogn. (Melastomataceae). Asian Pacific Journal of Tropical Biomedicine. 4 (suppl 2), S672 - S678. doi: 10.12980 / APJTB.4.201414B214.

34. Ihwan., \& Koda, S.H.A. (2017). Antimalarial Herbal Plants in Kupang, Indonesia. Bioscience. 9 (1). 95-104.

35. Abdillah, S., Tambunan, RM, Sinaga, YM, and Farida, Y. (2014). Ethno-botanical survey of plants used in the traditional treatment of malaria in Sei Kepayang, Asahan of North Sumatra. Asian Pac J Trop Med; 7(Suppl 1): S104-S107.

36. Abdillah, S., Tambunan, R.M., Farida, Y., Sandhiutami, N.M. D., \& Dewi, R.M. (2015). Phytochemical screening and antimalarial activity of some plants traditionally used in Indonesia. Asian Pacific J. Trop. Dis., 5 (6) 454-457.

37. Le Nguyen Tu Linh, B. D., Thach, T. T. L. G., Vũ Quang Dao, T. T. B., Nguyen Pham Ai Uyen, D. T., \& Cang, N. T. H. (2017). INHIBITOR XANTHINE OXIDASE OF EXTRACT BLUMEA BALSAMIFERA L.(DC) LEAVES (ASTERACEAE). European Journal of Research in Medical Sciences Vol, 5(1)16-23.
38. Spanou, C., Veskoukis, A. S., Kerasioti, T., Kontou, M., Angelis, A., Aligiannis, N., ... \& Kouretas, D. (2012). Flavonoid glycosides isolated from unique legume plant extracts as novel inhibitors of xanthine oxidase. PLoS One, 7(3), e32214.

39. Setyati, W.A., Zainuddin, M., \& Pramesti, R. (2017). Antioxidant Activity of Non-Polar And Polar Compounds From Macroalgae Acanthophora Muscoides Extract From The Krakal Beach Yogyakarta. Enggano's Journal. 2 (1), 68-77.

40. Sa'adah, H., Nurhasnawati, H., Permatasari V. (2017). The Effect of Extraction Method on Flavonoid Levels of Ethanol Extract of Dayak Bulbs (Eleutherine palmifolia (L.) Merr) by Spectrophotometric Method. Journal of Borneo Journal of Pharmascientech, 1 (1), 1-9.

41. Susanty., \& Bachmid, F. (2016). Comparison of Maceration and Reflux Extraction Methods on Phenolic Content of Corn Cob (Zea Mays L.) Extract. Conversion, 5 (2), 87-93

42. Sie, J.O. (2013). Antioxidant Power of Ethanol Extract of Mangosteen Rind (Garcinia Mangostana Linn.) Result of Stirring and Reflux. Calyptra. 2: 110.

43. Septiana, E., Umaroh, A., Gangga, E., \& Simanjuntak, P. (2017). Inhibition of Heme Polymerization Activity of Sembung Leaf Extract (Blumea balsamifera) as Antimalarial. Research Bulletin of Spices and Medicinesvol. 28 (1), 29-36. doi: 10.21082 / bullittro.v28n1.2017.29-36.

44. Sopianti, D.S., Novia, D., \& Setiawan, A. (2019). Identification of Secondary Metabolite Compounds from CapoLeaves (Blumea balsamifera (L.) DC) with Comparison of Extraction Methods. Scientific Journal of Farmacy, 6 (1), 12-18.

45. Yuan, Y., Huang, M., Pang, YX, Yu, FL, Chen, C., Liu, L, W., Chen, ZX, Zhang, YB, Chen, XL, and $\mathrm{Hu}, \mathrm{X}$. (2016). Variations in essential oil yield, composition, and antioxidant activity of different plant organs from Blumea balsamifera (L.) DC. at different growth times. Molecules, 21 (8), 2-13. doi: 10.3390 / molecules21081024. 